\title{
Effect of Phosphorus Fertilizer Levels on Growth and Root Character of Chickpea (Cicer Arietinum L.) Varieties in West Showa Zone, Ejersa Lafo, Ethiopia
}

\author{
Chala Chalchissa $^{1} \quad$ Habtamu Ashagire $^{2} \quad$ Ibrahim Hamza $^{3}$ \\ 1.Ethiopian Institute of Agricultural Research, Ambo Agricultural Research Center, P. O. Box 37, Ambo, Ethiopia \\ 2.Ambo University, College of Agriculture and Veterinary Sciences, P. O. Box 19, Ambo, Ethiopia \\ 3.Federal University of Technology Minna, School of Agriculture and Agricultural Technology, Department of \\ Crop production Technology
}

\begin{abstract}
Chickpea is one of the most important staple pulse crops in Ethiopia. However, its growth is constrained by a number of problems out of which fertilizer rates and varieties are the most important ones. Therefore, a field experiment was conducted in 2016 cropping season to determine the effect of phosphorus fertilizer levels on growth and root character of chickpea varieties at Ejersa Lafo district, central Ethiopia. Treatments consisted of four chickpea varieties (Dalota, Teketay, Natoli and Local check) and four phosphorus rates (0,23, 46 and $69 \mathrm{~kg}$ $\mathrm{P}_{2} \mathrm{O}_{5} \mathrm{ha}^{-1}$ ) arranged in a randomized complete block design with three replications. The results revealed that main effect of both phosphorus rates and varieties were highly significant $(\mathrm{P}<0.001)$ on plant height, number of primary branches, number of secondary branches, root length and number of pods per plant. Significantly higher number of primary branches plant- ${ }^{1}$ (5.37) was obtained from Teketay variety, higher root (14.33) and number of nodules plan-1(62.48) were obtained from Natoli variety and higher plant height (51.02) and number of secondary branches plant- ${ }^{1}(14.58)$ were obtained from local variety with application of $46 \mathrm{~kg} \mathrm{P}_{2} \mathrm{O}_{5} \mathrm{ha}^{-1}$. Therefor, application of phosphorus at the rate of $46 \mathrm{~kg} \mathrm{P}_{2} \mathrm{O}_{5}$ ha- ${ }^{1}$ was recommended for higher growth and root character of chickpea at study area.
\end{abstract}

Keywords: Chickpea, Phosphorus levels, Growth and Root character

DOI: $10.7176 / J N S R / 11-13-04$

Publication date:July $31^{\text {st }} 2020$

\section{Introduction}

Chickpea (Cicer arietinum L.) is an important pulse crop cultivated and consumed across the world. It is the third most important pulse crop in the world, after dry bean and field pea (FAOSTAT, 2013). The major producers are India, Pakistan, Turkey, Australia, Iran, Myanmar, Canada, Ethiopia, Mexico and Iraq with over 93\% of the global production (Upadhyaya et al., 2008). Most of the chickpea is produced with rainfall under marginal situation in developing countries (Toker et al., 2007). In Africa, chickpea is widely grown in Ethiopia, Sudan, Eritrea, Kenya, Tanzania and Malawi (Bejiga and Maesen, 2006). In Ethiopia chickpea is an important staple pulse crop and leads in production and area under cultivation next to faba bean and haricot bean (CSA, 2017). It is grown in several regions of the country with residual moisture on black vertisol soils (Kassie et al., 2009). Chickpea is produced for different purposes including food and feed, cash and foreign currency earning. In addition to these it served as a break crop since it improves soil fertility through biological nitrogen fixation. During 2016/17 Ethiopia produced $499,925.55$ ton of chickpea from an area of 242,703.3 ha with average productivity of 2.06 ton ha-1 $(\mathrm{CSA}, 2017)$ which is less than half of the global chickpea production potential $\left(5\right.$ ton ha- $\left.{ }^{-1}\right)$. In most chickpea growing areas of the world the main constraints reported to affect chickpea production are lack of high yielding varieties, limited use of fertilizers, abiotic and biotic stresses (Upadhyaya et al., 2011). From these constraints lack of high yielding varieties and limited use of fertilizers (especially phosphorus fertilizer) are the major limiting factors of chickpea in the study area. Even though there is no research recommendation on fertilizer application for chickpea production in the study area, farmers grows chickpea on marginal lands using local varieties with little fertilizer application.

Phosphorus is a major nutrient element required for proper growth and yield of grain legumes. Ryan et al. (2012) has clearly demonstrated the significance of phosphorus for all animals and plant life on the earth. Sharma et al. (2014) reported that the application of phosphorus was found to increase the production of pulse crops. Islam et al. (2011) also found that there is a positive yield response of chickpea to phosphorus fertilizer. Shivakumar et al. (2004) reported that the growth attributes like plant height, branches per plant and dry matter accumulation were increased with increasing level of $\mathrm{P}_{2} \mathrm{O}_{5}$ up to $80 \mathrm{~kg} \mathrm{ha}^{-1}$ over control in chickpea. Application of mineral $\mathrm{P}$ fertilizer at $46.5 \mathrm{~kg} \mathrm{P}_{2} \mathrm{O}_{5}$ ha $^{-1}$ result in a significant increase in growth characters of chickpea over control (Ahmed and Badr, 2009). It is essential in efficient and early root development, enhanced nodulation, leaf size, tillering, flowering, grain yield, and fastens maturity (Memon et al., 2016). It also plays an important role in photosynthesis process and storage and transfer of energy and sugar and starch utilization by being constituent of energy rich 
compounds viz. adenosine triphosphate (ATP) and adenosine diphosphate (ADP). Many biochemical reactions cannot be carried out unless the phosphate in high energy compounds (ATP, ADP) is transferred to other energy requiring molecules in the plant (Green and Sharma, 2012). In leguminous crops, the requirement of P as ATP or ADP compounds is not only vital but much higher due to symbiotic fixation of $\mathrm{N}$ (Uddin et al., 2014). Legumes generally have higher $P$ requirement because the process of symbiotic nitrogen fixation consumes a lot of energy (Schulze et al., 2006). Besides limited use of fertilizers luck of high yielding varieties is another limiting factor of chickpea production in the study area. Selection of suitable variety plays a vital role in crop production. The choice of right variety of chickpea helps in increasing crop productivity. Therefore, the study was planned with the objective of to evaluate the effect of different levels of phosphorus fertilizers on growth and root character of chickpea varieties in Ejersa Lafo district.

\section{Materials and Methods \\ Description of the study area}

The study was conducted in Ejersa Lafo district at $\left(09^{0} 33^{\prime} 412^{\prime \prime} \mathrm{N}\right.$ latitude and $038^{0} 14^{\prime} 697$ "E longitude with altitude of 2154m above sea level) in West Showa Zone, Oromia National Regional State of Ethiopia during 2016/2017 cropping season. The study area has a bimodal type of rainfall pattern with a total precipitation of $1339.8 \mathrm{~mm}$ per annum. The 2016 year mean maximum and mean minimum temperatures were $24.4^{\circ} \mathrm{C}$ and $8.7^{\circ} \mathrm{C}$ respectively with $56.4 \%$ average $\mathrm{RH}$.

\section{Experimental design, land preparation and treatments}

The experiment consisted of a factorial combinations of four Desi type chickpea varieties (Dalota, Teketay, Natoli which are improved varieties and one local variety (Mucha lame)) with four Phosphorus fertilizer rates (0, 23, 46 and $69 \mathrm{~kg} \mathrm{P}_{2} \mathrm{O}_{5} \mathrm{ha}^{-1}$ ) which were laid down in a randomized complete block design in three replications in a factorial fashion of $4 \times 4 \times 3$ arrangement. Each plot size measured $3 \mathrm{~m} \times 2.4 \mathrm{~m}\left(7.2 \mathrm{~m}^{2}\right)$ consisting of 8 rows of 0.3 $\mathrm{m}$ apart and $3 \mathrm{~m}$ in length, while the net plot size measured $2.8 \mathrm{~m} \times 1.8 \mathrm{~m}\left(5.04 \mathrm{~m}^{2}\right)$. The spacing between plots and replications were $0.5 \mathrm{~m}$ and $1 \mathrm{~m}$ respectively. The experimental field was ploughed by oxen, and land leveling done manually prior to planting. The seed was treated with Apron star before planting and two seeds were planted per holes on the $15^{\text {th }}$ of September 2016 and thinned to 2 plants per stand. Nitrogen fertilizer in the form of urea was applied as starter dose at the rate of $20 \mathrm{~kg} \mathrm{~N} \mathrm{ha}^{-1}$ to all plots at planting and Phosphorus fertilizer in the form of TSP (Triple super phosphate) was applied as per the treatments at planting. Crop management practices such as weeding, thinning and plant protection measure were done as per requirement equally for all treatments.

\section{Soil sampling}

Composite soil sample was collected at $0-30 \mathrm{~cm}$ depths before fertilizer application/planting and this was analyzed for physical and chemical properties, texture, available $\mathrm{P}$, total $\mathrm{N}, \mathrm{pH}$, organic carbon and exchangeable bases at National soil testing laboratory.

\section{Data collection}

Data was collected from the four middle rows for plant height (PH), Number of primary branches per plant (NPB), Number of secondary branches per plant (NSB), Root length (RL) and Number of nodules per plant.

\section{Data Analysis}

Data were subjected to the analysis of variance (ANOVA) appropriate to the design of the experiment (Gomez and Gomez, 1984) using SAS 9.4 and treatment means were separated by Duncan test at 5\% significance

\section{Results and Discussion}

Soil Analysis data: The physical and chemical properties of top soil $(0-30 \mathrm{~cm})$ before sowing were presented in (Table 1). The soil texture of experimental site was silty-clay with the $\mathrm{pH}$ value of 7.57 which was slightly basic and with Cation Exchange Capacity (CEC) of $57.38 \mathrm{Cmol}(+) / \mathrm{kg}$.

Table 1. Soil physical and chemical analysis result before planting

\begin{tabular}{ccccccccccc}
\hline PH & EC & Total & Ava P & $\mathrm{K}$ & OC & \multicolumn{2}{c}{ CEC } & \multicolumn{2}{c}{ Texture (\%) } & Textural \\
$1: 2.5(\mathrm{H} 2 \mathrm{o})$ & $\mathrm{ds} / \mathrm{m}$ & $\mathrm{N} \%$ & $\mathrm{ppm}$ & $\mathrm{Cmol}(+) / \mathrm{kg}$ & $\%$ & $\mathrm{Cmol}(+) / \mathrm{kg}$ & Sand & Silt & Clay & Class \\
\hline 7.57 & 0.53 & 0.08 & 3.3 & 1.08 & 0.88 & 57.38 & 15 & 51 & 34 & Silty-Clay \\
\hline
\end{tabular}

$\mathrm{OC}=$ organic Carbon; $\mathrm{TN}=$ Total Nitrogen; AVP=Total Available Phosphorus; $\mathrm{CEC}=$ Cation Exchange

Capacity, EC=Exchangeable Cation; $\mathrm{K}=$ Potassium

Analysis of Variance (ANNOVA): Analysis of variance showed that varieties and different phosphorus levels significantly $(\mathrm{P}<0.001)$ affected the plant height, number of primary branches, number of secondary branches, root length and number nodules per plant of chickpea under study. The interaction effect was non- significant for all parameter as presented in table 2 . 
Table 2: Analysis of variance for the effect of different levels of phosphorus fertilizer on growth and root character of chickpea varieties.

\begin{tabular}{|c|c|c|c|c|c|c|}
\hline \multirow{3}{*}{$\begin{array}{l}\text { Source of } \\
\text { Variation }\end{array}$} & \multirow{2}{*}{$\mathrm{df}$} & $\mathrm{PH}$ & NPB & NSB & RL & NPP \\
\hline & & \multicolumn{5}{|c|}{ MSB } \\
\hline & & $72.8531583 * *$ & & & & \\
\hline \multirow[t]{2}{*}{ Rep } & \multirow[t]{2}{*}{2} & & $0.22395833 * *$ & $0.08687500 \mathrm{NS}$ & $2.34247708 *$ & $27.030833 \mathrm{NS}$ \\
\hline & & $54.8737021 * *$ & $0.51722222 * *$ & $20.46520833^{* *}$ & & $1880.404444 * *$ \\
\hline \multirow[t]{2}{*}{ Var } & \multirow[t]{2}{*}{3} & $*$ & $*$ & $*$ & $5.05460833^{* *}$ & $*$ \\
\hline & & $92.1348188 * *$ & $3.18333333 * *$ & $16.21243056^{* *}$ & $18.05888056 * *$ & \\
\hline Fer & 3 & $*$ & $*$ & $*$ & $*$ & $137.291111 * * *$ \\
\hline Var*Fer & 9 & $3.8446225 \mathrm{NS}$ & $0.02574074 \mathrm{NS}$ & $0.26891204 \mathrm{NS}$ & $0.36213241 \mathrm{NS}$ & $1.734074 \mathrm{NS}$ \\
\hline Error & 30 & 4.5927939 & 0.02884722 & 0.1675417 & 0.56433264 & 9.093056 \\
\hline CV $(\%)$ & & 4.43 & 3.35 & 3.2 & 5.6 & 6.2 \\
\hline
\end{tabular}

\section{Plant height (cm)}

The analysis of variance indicated that plant height was significantly $(\mathrm{P}<0.001)$ affected only by the main effect of varieties and phosphorus rates (Table 3 ). The result revealed that the highest plant height (51.02) was recorded from local variety, while the lowest plant height (46.59) was recorded from Natoli variety. The difference between Natoli and Dalota was statistically at par. Numerically, Dalota variety gave the highest plant height. The maximum plant height (51.83) was recorded from application of $46 \mathrm{~kg} \mathrm{P}_{2} \mathrm{O}_{5} \mathrm{ha}^{-1}$, while the minimum plant height (45.34) was recorded from control, where phosphorus was not applied. The mean plant height increased with increased phosphorus fertilizer rates. Increased in plant height with increased rate of $\mathrm{P}_{2} \mathrm{O}_{5}$ for all varieties might be due to phosphorus fertilizer contributes to availability of soil nutrients which increases their uptake by plants. This result was agreed with the findings of Ahmed and Badr (2009), who reported that application of mineral P fertilizer at $46.5 \mathrm{~kg} \mathrm{P}_{2} \mathrm{O}_{5} \mathrm{ha}^{-1}$ result in a significant increase in growth characters (plant height) of chickpea over control. It also more supported with the finding of Yadav et al. (2014), who reported that increases phosphorus application rates up to optimum level increasing plant height of chickpea.

\section{Number of primary branches per plant}

The analysis of variance indicated that number of primary branches plant- ${ }^{1}$ was significantly $(\mathrm{P}<0.001)$ affected by the main effect of varieties and phosphorus rates, while the interaction effect was not significant (Table 3 ). The result indicated that Teketay variety produced significantly higher number of primary branches per plant (5.37), while Dalote variety produced significantly lower number of primary branches per plant (4.91). The difference between Dalota, Natoli and Local varieties were statistically at par. Numerically, Local variety gave the highest number of primary branches per plant. The maximum number of primary branches plant ${ }^{-1}$ (5.56) was recorded from application of $46 \mathrm{~kg} \mathrm{P}_{2} \mathrm{O}_{5} \mathrm{ha}^{-1}$, while the minimum number of primary branches plant- ${ }^{-1}$ (4.34) was recorded from control, where phosphorus was not applied. There was non-significant difference between application of 23 $\mathrm{kg} \mathrm{P}_{2} \mathrm{O}_{5}$ ha- $^{1}$ and $69 \mathrm{~kg} \mathrm{P}_{2} \mathrm{O}_{5}$ ha- ${ }^{1}$. The mean number of primary branches plant ${ }^{1}$ increased with increased phosphorus fertilizer rates. Increasing in number of primary branches per plant might be due to the cumulative effect of phosphorus on the processes of cell division and balanced nutrition. This result was agreed with the findings of Kumar et al. (2009), and Yadav et al. (2014), who reported that application of Phosphorus up to 50kg $\mathrm{P}_{2} \mathrm{O}_{5}$ ha $^{-1}$ significantly increased number of primary branches plant $\mathrm{t}^{-1}$ in chickpea over control. Similarly, it also supported with Meseret and Amin (2014), who reported that the number of branches per plant increases with increasing phosphorus application rates up to optimum level. 
Table 3: The main effect of varieties and phosphorus fertilizer levels on Plant height, № of primary branches plant- ${ }^{1}$ and № of secondary branches plant- ${ }^{1}$ of chickpea.

\begin{tabular}{lccc}
\hline Treatment & PH & NPB & NSB \\
\hline Varieties & & & \\
Dalota & $46.64 \mathrm{c}$ & $4.91 \mathrm{~b}$ & $12.41 \mathrm{~b}$ \\
Taketay & $49.10 \mathrm{~b}$ & $5.37 \mathrm{a}$ & $12.68 \mathrm{~b}$ \\
Natoli & $46.59 \mathrm{c}$ & $4.95 \mathrm{~b}$ & $11.46 \mathrm{c}$ \\
Local & $51.02 \mathrm{a}$ & $5.04 \mathrm{~b}$ & $14.58 \mathrm{a}$ \\
DMRT $(0.05)$ & $* * *$ & $* * *$ & $* *$ \\
\hline Phosphorus levels & & & $11.63 \mathrm{c}$ \\
\hline 0 & $45.34 \mathrm{~d}$ & $4.34 \mathrm{c}$ & $12.4 \mathrm{~b}$ \\
23 & $47.18 \mathrm{c}$ & $5.16 \mathrm{~b}$ & $14.38 \mathrm{a}$ \\
46 & $51.83 \mathrm{a}$ & $5.56 \mathrm{a}$ & $12.72 \mathrm{~b}$ \\
69 & $49.01 \mathrm{~b}$ & $5.21 \mathrm{~b}$ & $* * *$ \\
DMRT $(0.05)$ & $* * *$ & $* * *$ & 3.2 \\
CV $(\%)$ & 4.43 & 3.35 & $\mathrm{D}$ \\
\hline
\end{tabular}

Means followed by different letters in columns are statistically significant at $5 \%$ probability level using Duncan test.

\section{Number of secondary branches per plant}

The analysis of variance indicated that number of secondary branches plant- ${ }^{1}$ was significantly $(\mathrm{P}<0.001)$ affected only by the main effect of varieties and phosphorus rates (Table 3 ). The highest number of secondary branches plant- $^{1}$ (14.58) was recorded from Local variety, while the lowest number of secondary branches plant- ${ }^{1}(11.46)$ was recorded for the Natoli variety. There was non-significant difference between Dalota and Teketay varieties. The maximum number of secondary branches plant- ${ }^{-1}$ (14.38) was recorded from application of $46 \mathrm{~kg} \mathrm{P}_{2} \mathrm{O}_{5} \mathrm{ha}^{-1}$, while the minimum number of secondary branches plant- ${ }^{-1}$ (11.63) was recorded from control. The effects of $23 \mathrm{~kg}$ $\mathrm{P}_{2} \mathrm{O}_{5}$ ha- $^{1}$ and $69 \mathrm{~kg} \mathrm{P}_{2} \mathrm{O}_{5}$ ha- $^{1}$ were statistically at par. The mean number of secondary branches plant- ${ }^{1}$ increased with increased phosphorus fertilizer rates. Increasing in number of secondary branches per plant might be due to the cumulative effect of phosphorus on the processes of cell division and balanced nutrition. This result was supported with the findings of Yadav et. al. (2014), who reported that increasing phosphorus rates increases secondary branches per plant of chickpea.

\section{Root length (cm)}

The analysis of variance indicated that root length was significantly $(\mathrm{P}<0.01)$ affected only by the main effect of varieties and phosphorus rates (Table 4). The highest root length (14.33) was recorded from Natoli variety, while the lowest root length (12.92) was recorded for the Dalota variety. The difference between Dalota, Teketay and Local varieties were statistically at par. Numerically, Teketay variety gave the highest root length. The highest root length (14.86) was recorded from application of $46 \mathrm{~kg} \mathrm{P}_{2} \mathrm{O}_{5} \mathrm{ha}^{-1}$, while the lowest root length (11.88) was recorded from control, where phosphorus was not applied. There was non-significant difference between application of $23 \mathrm{~kg} \mathrm{P}_{2} \mathrm{O}_{5} \mathrm{ha}^{-1}$ and $69 \mathrm{~kg} \mathrm{P}_{2} \mathrm{O}_{5} \mathrm{ha}^{-1}$. The mean root length increased with increased phosphorus fertilizer rates. Increasing in root length might be due to that phosphorus encourages the formation of new cells and thus promotes the root and shoot growth. This result was in line with the findings of Dhage et al. (2014), who reported that application of phosphorus levels significantly increased the root length of soybean over control.

\section{Number of nodules per plant}

The analysis of variance showed that number of nodules plant- ${ }^{1}$ was significantly $(\mathrm{P}<0.001)$ affected by the main effect of varieties and phosphorus rates, while there is non-significant interaction effect (Table 4). The highest number of nodules plant- ${ }^{1}$ (62.48) was recorded from Natoli variety, while the minimum number of nodules plant${ }^{1}$ (32.08) was recorded from local variety. There was no significant difference observed between Teketay and Dalota varieties in case of number of nodules plant- ${ }^{1}$. The maximum number of nodules plant- ${ }^{1}$ (52.38) was recorded from application $46 \mathrm{~kg} \mathrm{P}_{2} \mathrm{O}_{5}$ ha $^{-1}$, while the minimum number of nodules plant- ${ }^{1}$ (44.15) was recorded from control. The effects of $23 \mathrm{~kg} \mathrm{P}_{2} \mathrm{O}_{5}$ ha- ${ }^{1}$ and $69 \mathrm{~kg} \mathrm{P}_{2} \mathrm{O}_{5}$ ha- ${ }^{1}$ were statistically at par. The mean number of nodules plant- ${ }^{1}$ increased with increased phosphorus fertilizer rates. Increasing in number of nodules plant- ${ }^{1}$ might be due to the fact that application of phosphorus results profuse growth of roots which ultimately resulted formation of more number of nodules of large size. This result was agreed with the findings of Yadav et al. (2014), who reported that growth characters and number of root nodules/plant increased with increasing level of phosphorus fertilizer significantly up to $50 \mathrm{~kg} \mathrm{P}_{2} \mathrm{O}_{5}$ ha- $^{1}$ on chickpea. 
Table 4: The main effect of varieties and phosphorus fertilizer levels on Root length and Nodules per plant of chickpea

\begin{tabular}{lcc}
\hline Treatment & RL & NPP \\
\hline Varieties & & \\
Dalota & $12.92 \mathrm{~b}$ & $48.55 \mathrm{~b}$ \\
Taketay & $13.35 \mathrm{~b}$ & $50.75 \mathrm{~b}$ \\
Natoli & $14.33 \mathrm{a}$ & $62.48 \mathrm{a}$ \\
Local & $12.98 \mathrm{~b}$ & $32.08 \mathrm{c}$ \\
DMRT (0.05) & $* *$ & $* * *$ \\
\hline Phosphorus levels & & $44.15 \mathrm{c}$ \\
\hline 0 & $11.88 \mathrm{c}$ & $48.3 \mathrm{~b}$ \\
23 & $13.23 \mathrm{~b}$ & $52.38 \mathrm{a}$ \\
46 & $14.86 \mathrm{a}$ & $49.03 \mathrm{~b}$ \\
69 & $13.62 \mathrm{~b}$ & $* * *$ \\
DMRT $(0.05)$ & $* * *$ & 6.2 \\
\hline
\end{tabular}

Means followed by different letters in columns are statistically significant at 5\% probability levels using Duncan test.

\section{Conclusion and recommendation}

This study result shows that out of four varieties, Teketay variety has better performance in number of primary branches plant- ${ }^{1}$, Natoli variety showed higher root length and number of nodules plan- ${ }^{1}$ while, local variety showed higher plant height and number of secondary branches plant- ${ }^{1}$ with the application of $46 \mathrm{~kg}^{\mathrm{P}_{2} \mathrm{O}_{5}} \mathrm{ha}^{-}{ }^{1}$. Therefore, application of phosphorus at the rate of $46 \mathrm{~kg} \mathrm{P}_{2} \mathrm{O}_{5}$ ha- $^{1}$ was recommended for higher plant height, number primary and secondary branches plant- ${ }^{1}$, root length and nodules plant- ${ }^{1}$ of chickpea at study area. However, this research was conducted at one location and one year it should be better to repeat the experiment in multi locations and years so as to assure the results of this experiment.

\section{REFERENCES}

Ahmed, M.A. and Badr, E.A. 2009. Effect of bio and mineral phosphorus fertilizer on growth, productivity and nutritional value of some chickpea cultivars (Cicer arietinumL.) in newly cultivated land. Austr. Journal of Basic. appl. Sci. 3:4656-4664.

Bejiga, G. and van der Maesen, L.J.G. (2006). Cicer arietinum L. Plant Resources of Tropical Africa 1: Cereals and Pulses, pp. 42-46, (Brink, M. and Belay, G., eds). PROTA Foundation, Wageningen, Netherlands/Backhuys Publishers, Leiden, Netherlands/CTA, Wageningen, Netherlands.

Central Statistical Agency (CSA), 2017. The Federal Democratic Republic of Ethiopia, Agricultural Sample Survey. Report on Area and Production of Major Crop. Volume 1 addis Ababa

Dhage, S.J., Patil, V.D. and Dhamak, A.L., 2014. Influence of phosphorus and sulphur levels on nodulation, growth parameters and yield of soybean (Glycine max L.) grown on Vertisol. Asian Journal of Soil Science, 9(2):244249.

Food and Agricultural Organization of the United Nations. FAOSTAT. 2013. [online] Available at http:/faostat.fao.org/site/339/default.aspx, 2013 for Agricultural Research in the Dry Areas. Aleppo Syria.

Green, L.H. and G. Shama. Basic Cell Biology, 2012. P. 7598. In: Laroussi, M. et al. (eds.) Plasma Medicine Applications of Low Temperature Gas Plasmas in Medicine and Biology Cambridge. Cambridge University Press, UK.

Islam, M.S., Mohsan S., Afzal, S., Akmal M.A. and Khalid, R. 2011. Phosphorus and sulfur application improves the chickpea productivity under rain fed conditions. International journal of Agric. Biol. 13: 713-718.

Kassie, M., Shiferaw, B., Asfaw, S., Abate, T., Muricho, G., Ferede, S., Eshete, M. and Assefa, K. (2009). Current situation and future outlooks of the chickpea sub-sector in Ethiopia. ICRISAT and EIAR.

Kumar, V., Dwivedi, VN.and Tiwari, DD. 2009. Effect of Phosphorus and Iron on yield and mineral nutrition in chickpea. Ann. Plant Soil. Res. 11:16-18.

Memon, M., Rajput, A.N., Rajput, A., Jamro, G.M. and Kumbhar, M.I., 2016. Response of chickpea cultivars to phosphorus application. Soil \& Environment, 35(1):22-29

Ryan, J., Ibrikci, H., Delgado, A., Torrent, J., Sommer, R. and Rashid. A. 2012. Significance of phosphorus for agriculture and the environment in the West Asia and North Africa region. Advances in Agronomy .114:91153.

Schulze, J., Temple, G., Temple, S.J., Beschow, H. and Vance, C.P., 2006. Nitrogen fixation by white lupin under phosphorus deficiency. Annals of Botany, 98(4), pp.731-740.

Sharma, A.k., Raghubanshi, B.P.S. and Sirothia, P. 2014. Response of chickpea to levels of zink and Phosphorus. 
Annals of Plant and Soil Research 16 (2):172-173

Shivakumar, Bs., Balloli, SS., Saraf, CS. 2004. Effect of source and levels of phosphorus with and without seed inoculation on the performance of rain fed chickpea. Ann. Agric. Res. New Series. 25:320-326.

Toker, C., Canci, H. and Yildirim, T. (2007). Evaluation of perennial wild Cicer species for drought resistance. Genetic Resources and Crop Evolution (DOI 10.1007/s10722-006-9197-y).

Turuko, M. and Mohammed, A., 2014. Effect of different phosphorus fertilizer rates on growth, dry matter yield and yield components of common bean (Phaseolus vulgaris L.). World Journal of Agricultural Research, 2(3), pp.88-92.

Uddin, M. S. Hussain, M. M. A. Khan, N. Hashmi, M. Idrees, M. Naeem and T.A. Dar. 2014. Use of N and P biofertilizers reduces inorganic phosphorus application and increases nutrient uptake, yield, and seed quality of chickpea. Turkish Journal of Agriculture and Forestry 38: 47-54.

Upadhyaya, H.D., Dwivedi, S.L., Baum, M., Varshney, R.K., Udupa, S.M., Gowda, C.L.L., Hoisington, D. and Singh, S. (2008). Genetic structure, diversity, and allelic richness in composite collection and reference set in chickpea (Cicer arietinum L.). BMC Plant Biology.

Upadhyaya, H.D., Thudi, M., Dronavalli, N., Gujaria, N., Singh, S., Sharma, S. and Varshney, R.K. 2011. Genomic Tools and Germplasm Diversity for Chickpea Improvement. Plant Genetic Resour: Characterization and Utilization. 9 (1): 45-58.

Yadav, B.K. and Kumar, S., 2014. Performance of chickpea (cicer arietinum) under different levels of phosphorous and sulphur application. Plant Archives, 14(2), pp.1115-1117. 